\title{
AN INVESTIGATION OF PRIMARY SCHOOL STUDENTS' SELF REGULATORY LEARNING SKILLS
}

\author{
Kamil Arif KIRKIÇ ${ }^{1 *}$, Mustafa Metin SEVIMLİ ${ }^{2}$ Emin AYDIN ${ }^{3}$ \\ ${ }^{1}$ Assist. Prof. Dr., İstanbul Sabahattin Zaim University, TURKEY, kamil.kirkic@izu.edu.tr \\ ${ }^{2}$ Research Student, İstanbul Sabahattin Zaim University TURKEY, mmsevim13@gmail.com \\ ${ }^{3}$ Prof. Dr., Marmara University, TURKEY, eaydin@marmara.edu.tr \\ ${ }^{*}$ Corresponding Author
}

\begin{abstract}
Self-regulated learning is the ability of the student to carry out the learning process in order to be successful. The aim of the study is to determine the self-regulated learning skills of primary school students. In this study, descriptive survey model, which is one of the quantitative research design methods, was preferred. Descriptive survey model aims to describe the variables without any intervention to them. The study was carried out with the participation of elementary school students who attended a summer school, determined by the appropriate sampling method. A total of 71 primary school students participated in the study. Data were collected from students with the help of personal information forms and Self-Regulatory Learning-7 Scale. As classes progress, students are expected to acquire higher levels of self-regulated learning skills, as they spend more time in education. However, as a result of the analysis of students' Self-Regulatory Learning-7 Scale scores, it was determined that the differences between students in terms of class and gender were not significant.
\end{abstract}

Keywords: Self-regulatory learning, Primary school education Learning skills

\section{INTRODUCTION}

It is very important to consider the personal differences of individuals in the educational environment. Because, due to personal differences, some students easily understand the issues while others have difficulties to understand. It is seen that those who learn the lessons easily are very willing to work, and those who have difficulty have low motivation towards the lesson. For students with low motivation, it is necessary to prepare enriched environments with strategies and plans that will increase their motivation. The first person to be aware of the individual's personal differences is again the individual. For this reason, the individual needs to be aware of his/her condition and thus organize the learning process in his/her own way. In this process, self-regulated learning comes to the fore, which helps to regulate one's motivational processes, differences and learning stages.

\subsection{Self-Regulated Learning}

Self-regulated learning is the control over all stages in the individual's learning process, and everything in the 
process is under the control of the individual. According to Zimmerman, it involves setting realistic goals to successfully accomplish a task, using effective strategies that are appropriate for the individual, measuring the effectiveness of the strategies used, and adjusting these strategies accordingly when necessary (Zimmerman, 1989; ac. Sarı and Akınoğlu, 2009). Self-regulation is viewed from two different perspectives. One of these is metacognition, which includes the knowledge and awareness of the individuals about their own thoughts, and the other is social cognition that deals with the social factors affecting the individual (Aydın \& Atalay, 2015).

Metacognition is the ability to form strategies, to be aware of development, to solve problems, to think in detail and to evaluate the usefulness of ideas to gain the necessary knowledge. The main element of metacognition is to develop a plan and maintain the developed plan. There are two sub-elements of metacognition, cognition knowledge and cognition regulation (Schraw \& Moshman, 1995; act. Aydın and Atalay 2015). There are three sub-sections of cognition information that covers what one knows about cognition in general or about cognition they have. These include information about the factors that will affect the productivity of the individual, along with information about the other methods, procedural information, and conditional information covering when and which information is used. Regulation of cognition is the series of metacognitive actions that contribute to the control of learning and thinking under the individual (Schraw \& Moshman, 1995; act. Aydın and Atalay 2015). Regulation of cognition consists of three sub-sections. These are the arrangements, which include planning and selecting the right strategy, monitoring the self-test skills required for the control of learning, and monitoring the performance of the individual in addition to the learning process according to certain criteria.

Stability is one of the most important factors in the learning process. To have a good performance, a systematic perspective is required and the balance in the process must be maintained. Many factors such as motivation, attention, financial resources and time are required to maintain this balance. Without these factors, stability in the process is compromised, which means that learning will be negatively affected (Albert Ziegler et al., 2010). In order to ensure stability, it is necessary to manage the resources owned. Resource management strategies help students identify their needs in line with their goals, change their environment and adapt them to their environment when necessary (Aydın \& Atalay, 2015). Resource management strategies are grouped under four headings: time management, effort regulation, peer learning and seeking help.

Time management should be used to improve the academic performance that is necessary for the student to achieve success. The first element for time management is to stay away from the topics that will divert from the target and to remain fixed in the subjects necessary to reach the target, and to prioritize the topics in order of importance (Zimmerman \& Cleary, 2009; act. Aydın \& Atalay, 2015). Time management should include not only drawing the boundaries of the time worked, but also using the time used efficiently during the study. For this reason, the working environment should also be regulated. Time is not used efficiently if there are elements that can shift the focus in another direction (Pintrich and De Grot., 1990).

The regulation of effort is the ability of the student to act in relation to this task when he / she has to regulate the labor put forward in the process, keep it under control and perform an uninteresting duty. Effort management is an important factor to move forward with determined and confident steps even if obstacles are encountered. Learning from the screen covers their peers and helping each other in the process.

One of the most important factors in resource management strategies is seeking help. During the process, the learner should learn to ask for help from his/her environment. The process of getting help consists of five steps. These are awareness of the need for help, deciding on seeking help, identifying potential helpers, determining strategies for obtaining help, and evaluating the process of seeking help (Aleven at all, 2003; act. Aydın and Atalay 2015). If the individual uses his/her capacity to the fullest and still cannot find a solution to the problem he/she is facing, he / she should ask for help from a more competent person. This is called an adaptable request for help. In order to speak of adaptable help, firstly, a need for help must arise and it is necessary to learn not only the solution of the problem but also the ways to overcome that problem. Individuals can avoid asking for adaptable help because they think that they are inadequate, incompetent and not smart enough. Therefore, individuals must be encouraged to seek help. Adaptable help demand develops the individual's interest in the job in the short term and the continuity of the job, and how to solve these problems when faced with similar problems in the long term (Aydın and Atalay, 2015).

There are many factors that affect self-regulation skills such as age, gender, environment, and parental attitude (Daggul and Gürşimşek, 2019). A look at the studies on the subject shows that the self-regulation skills of female students are higher than the self-regulation skills of male students (Baysal and Özgenel, 2019; Daggul and Gürşimşek, 2019; Yaralı and Aytar 2017). The low number of studies on this subject 
prevents us from reaching a definitive judgment.

Another factor that affects the level of self-regulation skill is the age of the students (Tanribuyurdu, 2012). When the literature is examined, it is seen that the self-regulation skill increases as the students get older (Baysal \& Özgenel, 2019; Tanrıbuyurdu, 2012). It is suggested that the level of affecting students' learning profiles due to various variables such as different grade, gender, school level, intelligence and age should be the subject of future research (Leana-Taşçılar, 2015).

The aim of the study is to determine the self-regulated learning skills of primary school students. The problem of this study is "What are elementary school students' self-regulated learning skills?". Based on this problem, the answers are sought for the following sub-problems

1- What is the level of self-regulation skills of primary school students?

2- Do the self-regulation skills of primary school students differ according to the grade level?

3- Do the self-regulation skills of primary school students differ according to gender?

\section{METHOD}

In this study, descriptive survey model, which is one of the quantitative research design methods, was preferred. In the descriptive scanning model, it is aimed to describe the variables without any intervention on the them (Büyüköztürk, 2016; Karasar, 2017; Robson, 2017).

\subsection{Study Group}

The study was carried out with the participation of elementary school students who attended a summer school which was organized by a private school after the 2018-2019 academic year. The participants were determined by the appropriate sampling method,. A total of 71 primary school students participated in the study. $22(31 \%)$ of the students are female students, $49(69 \%)$ are male students. $20(28.2 \%)$ of the students consist of 2 nd grade, $42(59.2 \%)$ of 3rd grade and $9(12.7 \%)$ of 4 th grade students (Table 1$)$.

Table 1. Frequency and Percentage Values Regarding Students' Demographic Structure

\begin{tabular}{|l|l|l|l|}
\hline Variables & Groups & $f$ & $\%$ \\
\hline \multirow{2}{*}{ Gender } & Female & 22 & 55,9 \\
\cline { 2 - 4 } & Male & 49 & 44,1 \\
\hline \multirow{3}{*}{ Grade } & Grade 2 & 20 & 28,2 \\
\cline { 2 - 4 } & Grade 3 & 42 & 59,2 \\
\cline { 2 - 4 } & Grade 4 & 9 & 12,7 \\
\hline
\end{tabular}

\subsection{Data Collection Tools}

Questions were taken from students' personal information forms to learn about class, gender, academic achievement and educational status of parents. Gender and class information could be obtained from all of the students. However, some of the other necessary information could not be obtained from all participants.

The Self-Regulatory Learning-7 Scale (SRLS-7), developed by Ziegler et al. in 2012 and adapted to Turkish by Leana-Taşçılar (2015), was used. The scale is scored according to 3 different options (self-regulation, thoughtless-impulsive and externally controlled learning) profiles in 7 different steps over four different scenarios. The maximum score that can be obtained as self-regulation is 28 (Leana-Taşcılar, 2015), since it is scored as 1 or 0 in the total of 4 scenarios ( $7 \times 4)$ in 7 different steps in the scale.

\subsection{Data Analysis}

Collected data were analyzed with SPSS-25 package program. Kolmogorov-Smirnov (K-S) test results, conducted to determine whether the distribution of the data is normal, shows that the data are not distributed normally. 
Proceedings of SOCIOINT 2020- 7th International Conference on Education and Education of Social Sciences, 15-17 June 2020

Table 2. Self-Regulatory Learning-7 Scale (SRLS-7) Kolmogorov-Smirnov Test Results

\begin{tabular}{|l|l|l|l|}
\hline & Statistic & sd & $p$ \\
\hline SRLS--7 &, 126 & 71 &, 007 \\
\hline
\end{tabular}

The data in Table 2 show that the scores obtained from the scale do not show a normal distribution ( $p$ $<0.05)$ statistically. Since the data were not normally distributed, Mann Whitney $U$ and Kruskall Wallis nonparametric tests were used in the study.

\section{RESULTS}

In this section, the data obtained with the self-regulated learning scale applied to primary school students were analyzed. The analysis results are presented in the tables and briefly interpreted.

Table 3. Self-Regulatory Learning-7 Scale (SRLS-7) Average and Standard Deviation Values

\begin{tabular}{|l|l|l|l|}
\hline & N & X & Ss \\
\hline SRLS-7 & 71 & 16,31 & 7,015 \\
\hline
\end{tabular}

The data obtained for the first sub-problem were found to be the mean scores of the students who participated in the study (STS-7), as 16.31 . This average corresponds to $58.25 \%$ of the maximum score (28 points).

Table 4. Mann Whitney U test Results According to the Gender Variable of the Students' SelfRegulatory Learning-7 Scale (OAS-7) Scale Scores

\begin{tabular}{|c|c|c|c|c|c|c|}
\hline & Group & $\mathbf{N}$ & ST & U & z & p \\
\hline \multirow[b]{3}{*}{$\frac{\hat{s}}{\frac{\vec{d}}{\omega}}$} & Female & 22 & 925,50 & \multirow{3}{*}{405,500} & \multirow{3}{*}{$-1,663$} & \multirow{3}{*}{0,096} \\
\hline & Male & 49 & 1630,50 & & & \\
\hline & Total & 71 & & & & \\
\hline
\end{tabular}

Self-Regulatory Learning-7 Scale (OCD-7) does not differ statistically by gender ( $p>0.05)$.

Table 5. Kruskal Wallis-H Test Results to Determine Whether Students' Self-Regulatory Learning-7 Scale (SRLS-7)

\begin{tabular}{|c|c|c|c|c|c|c|}
\hline & Groups & $\mathbf{N}$ & S.O & df & $x^{2}$ & $p$ \\
\hline \multirow{4}{*}{$\begin{array}{l}\hat{1} \\
\vec{d} \\
\overrightarrow{0}\end{array}$} & 2 & 20 & 31,58 & \multirow{4}{*}{2} & \multirow{4}{*}{2,396} & \multirow{4}{*}{,302 } \\
\hline & 3 & 42 & 39,14 & & & \\
\hline & 4 & 9 & 31,17 & & & \\
\hline & Total & 71 & & & & \\
\hline
\end{tabular}

After the Kruskal Wallis-H analysis of the data obtained from the Self-Regulatory Learning-7 Scale (SRLS-7) scale, the mean of the rankings by class variable did not show a significant difference $\left(X^{2}=2.396 ; d f=2 ; p>\right.$ 0.05).

\section{CONCLUSION AND DISCUSSION}

As a result of the analysis of students' Self-Regulatory Learning-7 Scale scores, it was determined that the differences between students in terms of class and gender were not significant. As classes progress, 
students are expected to acquire higher levels of self-regulated learning skills, as they spend more time in education. However, the fact that there is no difference between the self-regulated learning levels between the classes may be because that these skills are not taught in primary school classes. The critical process in acquiring self-regulated learning skills is the effort shown to teach these skills (Can Aran, 2015). It was determined that there is a meaningful relationship between the age and class variables predicting the metacognitive learning strategies of prospective teachers studying at the Faculty of Education at the University (Başara Baydilek, Altay \& Saracaloğlu, 2018). While students who study at the university prepare for different entrance exams over the years, their metacognitive learning skills differentiate during 12-15 years of learning on different occasions, or they may not be attributed to the fact that their education period is short and not passed through similar examination processes.

In conclusion, elementary school students' self-regulated learning skill levels have been found to affect the students' school success positively in primary school classes (McDonald Connor, Cameron Ponitz, Phillips, Travis, Glasney \& Morrison, 2010). In the study conducted by Kuşdemir Kayıran and Doğanay, it was found that teaching Turkish with the self-regulatory learning model to fifth grade students contributes to the development of self-regulated learning skills as well as making students more successful in understanding what they read (2017). This finding of this study by Kuşdemir Kayıran and Doğanay implicitly supports the findings of the current study. Students who are not trained in self-regulated learning skills are unlikely to achieve these skills in primary school classes.

\section{RECOMMENDATIONS}

Firstly, teachers should be educated about self-regulated learning skills (Can Aran, 2015). These skills affect both teaching and learning processes positively, as indicated by the studies on the subject. Opening a place for "self-regulated learning skills" in the curriculum, instead of the concept of "learning to learn" in teaching programs will contribute to the acquisition of self-regulated learning skills to students and teachers.. Further research can be conducted on how students' education in acquiring self-regulated learning skills in primary school will affect their success in school.

\section{REFERENCE LIST}

Aydın, S. \& Atalay, T.D. (2015). Self-regulated learning. Ankara: Pegem A Academy.

Basara Baydilek, N., Altay, B., and Saracaloglu, A.S. (2018). Preschool, guidance and psychological counseling and determining the variables that predict the metacognitive learning strategies of the artprogram students. Kastamonu Education Journal, 26 (3), 707-720. doi: 10.24106 / kefdergi.413317

Baysal, A. and Özgenel M. (2019). Examining the relationship between middle school students' attachment styles and self-regulation levels. Journal of Theory and Practice in Education 15 (2), 142-152.

Büyüköztürk, Ş. (2019). Scientific research methods in education. Ankara: Pegem A Academy.

Büyüköztürk, Ş. (2018). Manual of data analysis for social sciences. Ankara: Pegem A Academy.

Can-Aran, Ö. (2015). The relationship between self-regulation and study skills. Pegem Education and Training Journal, 5 (2), 207-220, http://dx.doi.org/10.14527/pegegog.2015.011.

Daggul H. And Gürşimşek A. (2019). Investigating pre-school children's self-regulation skills in terms of various variables in Northern Cyprus, Pegem Education and Training Journal, 9 (2), 491-522

Karasar, N. (2017). Scientific research methods. Ankara: Nobel Publishing.

Kuşdemir Kayıran, B. \& Doğanay, A. (2017). To understand what Self-Regulatory learning is reading academic success and its impact on self-regulation skills. Journal of International Education Programs and Instructional Studies, 7 (14)

Leana Tasçılar, M.Z. (2015). Validity and Reliability Study of Questionnaire on Self-Regulated Learning -7 Turkish Version. Turkish Journal of Giftedness and Education, 5(1), 21-43.

McDonald Connor, C., Ponitz, C., Phillips, B.M., Travis, Q.M., Glasney, S., \& Morrison, F.J. (2010). First graders' literacy and self-regulation gains: The effect of individualizing student instruction. Journal of School Psychology 48, 433-455. 
Robson, C. (2017). Scientific research methods real world research. Ankara: Anı Publishing.

Pintrich, P. R., and De Groot, E. V. (1990). Motivational and self-regulated learning components of classroom academic performance. Journal of Educational Psychology, 82 (1), 33-40

Sarı, A. and Akınoğlu, O. (2009). Self-Regulated Learning: Models And Applications. Marmara University Atatürk Faculty of Education Journal of Educational Sciences, 29, 139-154.

Tanrıbuyurdu, E. (2012) Validity and reliability study of preschool self-regulation scale. (Master Thesis). Hacettepe University, Ankara.

Yaralı K. and Aytar F. (2017). Examining the behaviors of preschool children in terms of self-regulation skills. Mersin University Faculty of Education Journal, 13 (3), 856 - 870

Ziegler A., Fidelman M., Reutlinger M., Vialle M. \& Steoger H. (2010). Implicit personality theories on the modifiability and stability of the action repertoire as a meaningful framework for individual motivation: a cross-cultural study. High Ability Studies 21 (2), 147-163 